\title{
Incorporation by Reference in New York State
}

\author{
Bennett Liebman
}

Follow this and additional works at: https://digitalcommons.tourolaw.edu/lawreview

Part of the Administrative Law Commons, Legislation Commons, and the State and Local Government Law Commons

\section{Recommended Citation}

Liebman, Bennett (2021) "Incorporation by Reference in New York State," Touro Law Review. Vol. 37: No. 3, Article 8.

Available at: https://digitalcommons.tourolaw.edu/lawreview/vol37/iss3/8

This Article is brought to you for free and open access by Digital Commons @ Touro Law Center. It has been accepted for inclusion in Touro Law Review by an authorized editor of Digital Commons @ Touro Law Center. For more information, please contact Iross@tourolaw.edu. 


\title{
INCORPORATION BY REFERENCE IN NEW YORK STATE
}

\author{
Bennett Liebman*
}

\begin{abstract}
Incorporation by reference is a traditional procedural mechanism that allows for actors at each level of government to include all or parts of a previously enacted law into the newer version of the law by simply including a statement stating that the second law should be treated as if it was part of the primary law. While incorporation by reference could facilitate and streamline legislation, New York has seemingly banned incorporation by reference in Article III, $\S 16$ of the State Constitution. However, even though this ban is in place, there are several limitations and exceptions placed on the ban that make New York's policy regarding incorporation by reference potentially difficult to follow due to the lack of uniformity in the law. This article will discuss the policy issues surrounding incorporation by reference in the New York state legislature, agency regulations, and local government regulations as well as the exceptions involved in those policy issues. Furthermore, this article will give various
\end{abstract}

\footnotetext{
* Bennett Liebman is a Government Lawyer in Residence at the Government Law Center of Albany Law School. He has previously served as the Interim Director, the Acting Director and the Executive Director of the Government Law Center. In state government, he worked for Mario Cuomo while Cuomo was Secretary of State and served as his Counsel when he was Lieutenant Governor. Beginning in 1988, he served as a member of the New York State Racing and Wagering Board for more than a decade, including serving as its Acting Co-Chair. He concluded his government service in 2014 after three years as Deputy Secretary to the Governor for Gaming and Racing. He is a summa cum laude graduate of Union College and a cum laude graduate of New York University School of Law.
} 
suggestions to fix the issues in New York's incorporation by reference policy to make it more workable for the current legal environment.

\section{INTRODUCING INCORPORATION BY REFERENCE}

Incorporation by reference is a traditional technique used in drafting legislation and regulations at all levels of government. The entity authoring a new enactment may incorporate the terms of a prior enactment or prior standards in the terms of its new enactment.

An incorporative reference occurs whenever legislation references material outside of itself and indicates expressly or by implication that this material should be treated as if it were fully set forth at that point in the legislation. The requirements of the referenced material are then said to be "incorporated into" or "adopted into" the legislation that adopted them, without the necessity of printing the text verbatim. ${ }^{1}$

Incorporation by reference is a regular practice in legislatures throughout the United States.

Incorporation by reference formally involves the "method of making a secondary document part of a primary document by including in the primary document a statement that the secondary document should be treated as if it were contained within the primary one." 2 For all governments, an enactment "may incorporate by

\footnotetext{
${ }^{1}$ F. Scott Boyd, Looking Glass Law: Legislation by Reference in the States, 68 LA. L. REv. 1201, 1210 (2008). An official in the Canadian Department of Justice has similarly described incorporation by reference "as a drafting technique for providing that a legislative text (whether in primary legislation, such as a statute or subordinate legislation, such as a regulation) includes material (text, information, concepts) expressed elsewhere. The material is included without reproducing it word-for-word within the legislative text." John Mark Keyes, Incorporation by Reference in Legislation, 25 STATUTE L. REV. 180 (2004).

${ }^{2}$ Incorporation by Reference, Black's Law Dictionary (11th ed. 2019). See 1 CAL. CODE REGS. tit. 1, $\S 20$ (Barclay's 2021). “'Incorporation by reference' means the method whereby a regulation printed in the California Code of Regulations makes provisions of another document part of that regulation by reference to the other document." Id. at $\S 20$ (a). See also Kings Rehab. Ctr. v. Premo, 81 Cal. Rptr. 2d 406 (Cal. Ct. App. 1999); Friedman v. Goodman, 132 S.E.2d 60 (Ga. 1963); Stephen
} 
reference all or any part of a code, standard, or rule that has been adopted by an agency of the United States, this state, another state, or by a nationally recognized organization or association." 3

There are emerging issues of dynamic incorporation by reference. Most incorporations by reference incorporate static enactments - previously enacted legislation, rules, codes or standards. Sometimes, however, incorporation by reference is dynamic and allows the use of standards that are subject to future change. An example of a dynamic incorporation involves Article III, $\S 22$ of the New York State Constitution which authorizes the State to use future federal definitions of "income" for purposes of the state income tax in New York. ${ }^{4}$ This incorporation is dynamic and not static in that the definition of income is subject to change in the future by Congressional action.

Thus, as a practical matter, it makes little sense for the New York penal law provisions governing controlled substances to enumerate all the details on specific controlled substances. Instead, the penal law references the definitions of controlled substances articulated in public health law. ${ }^{5}$ Similarly, public health law provisions adopt federal Medicare fee restrictions ${ }^{6}$ and insurance regulations regularly encompass the standards of the National

S. Wu, Incorporation by Reference and Public Key Infrastructures: Moving the Law Beyond the Paper-Based World, 38 JURIMETRICS J. 317 (1998).

3 See Nat'l Conf. Comm'rs on Unif. State L., Revised Model State Administrative Procedure ACT: Draft for 2008 ANNUAl MeEting With PREFATORY NOTES AND COMMENTS (2008).

${ }^{4}$ N.Y. CONST. art. III, $\S 22$. The pertinent part of $\S 22$ reads that

the legislature, in any law imposing a tax or taxes on, in respect to or measured by income, may define the income on, in respect to or by which such tax or taxes are imposed or measured, by reference to any provision of the laws of the United States as the same may be or become effective at any time or from time to time....

Id. (emphasis added).

${ }^{5}$ See N.Y. Penal L. $\$ \S 220.00(5), 220.03,220.06,220.65$. See also Town of Islip v. Cuomo, 541 N.Y.S.2d 829 (App. Div. 1989); People v. Graff, 359 N.Y.S.2d 976 (Sup. Ct. 1974). "The generally restrictive interpretation of N.Y. Constitution, article III, $\S 16$ is further illustrated in those cases which uphold the various provisions of the Penal Law which incorporate by reference the terms of the statutes, such as those contained in the Public Health Law, which define narcotic drugs." Town of Islip, 541 N.Y.S. at 834.

${ }^{6}$ Medical Soc'y v. State Dep't of Health, 633 N.E.2d 468, 469 (N.Y. 1994). 
Association of Insurance Commissioners. ${ }^{7}$ This is incorporation by reference, and it is a regular feature of statutes, rules, and municipal enactments throughout the United States.

"Federal statutes adopt state law; municipalities adopt both state law and federal statutes; state statutes adopt state agency regulations, county ordinances, federal statutes, and federal agency regulations; and state regulations adopt state statutes, federal regulations, and federal statutes." ${ }^{\prime 8}$ Incorporation can save space and provide certainty. "Using incorporation, those laws achieve in just a few words the same effect as if they had recited, verbatim, long treatises." 9

New York State agencies regularly use incorporation by reference by referring to titles utilized in outside governmental publications, most frequently the Code of Federal Regulations or the Federal Register. At times, state agencies have similarly incorporated private sector standards. ${ }^{10}$

While incorporation by reference may seem commonplace there is an overarching problem with incorporation by reference within the New York State legislature. Under the New York State Constitution, legislation by reference would appear to be unconstitutional. Article III, $\S 16$ of the New York Constitution states, "No act shall be passed which shall provide that any existing law, or any part thereof, shall be made or deemed a part of said act, or which shall enact that any existing law, or part thereof, shall be applicable,

\footnotetext{
${ }^{7}$ Daniel Schwarcz, Is U.S. Insurance Regulation Unconstitutional?, 25 ConN. Ins. L. J. 191, 193-94 (2018).

${ }^{8}$ Boyd, supra note 1, at 1211. Professor Ernst Freund dates referential legislation in the United States as far back as 1836 to an early act of Louisiana (1836) providing that all municipalities shall each within its limits possess all powers then possessed and exercised by the city of New Orleans. See 1st Mun. of New Orleans v. McDonough, 2 Rob. 244, 248 (La. 1842); ERNST Freund, LegisLative Regulation, A Study of the Ways and Means of Written Law 45 (1932). See also Nicholas Quinn Rosencranz, Federal Rules of Statutory Interpretation, 5 HARV. L. REV. 2085, 2136-37 (2002) ("It would incorporate extant texts into statutes, and whether those texts were originally generated by a congressional committee or by the Oxford English Dictionary editorial board is constitutionally irrelevant.").

${ }^{9}$ Joshua M. Divine, Statutory Federalism and Criminal Law, 106 VA. L. REv. 127, 134 (2020).

${ }^{10}$ See N.Y.S. Dep't of State, New York State Register Procedure Manual 33-35 (1986). See references to the standards of the National Association of Insurance Commissioners at N.Y. COMP. CODES R. \& REGS. tit. 11, §§ 78.3, 125.2, 176.3 (2021).
} 
except by inserting it in such act."11 New York State, in theory, "directly prohibit[s] incorporation by reference in statutes." 12

Questions of incorporation by reference affect State legislation, State rules and regulations, and local enactments. While one might have assumed that a single New York standard would govern all incorporations by reference, that is hardly the case. Different standards apply to each level of government. This article will explore the issues involving incorporation by reference throughout the various levels of New York government and suggest a path by which some, but far from all, of these issues may be resolved.

\section{Public Policy Issues Affecting Incorporation by Reference}

While incorporation by reference may be all around us, there are reasons to be skeptical of certain aspects of incorporation.

In the nineteenth century, there were times when incorporation would be used unscrupulously. In an era where legislatures could be purchased de facto by major corporate interests, ${ }^{13}$ or where political party bosses could repurpose their party to serve as a criminal organization, ${ }^{14}$ incorporation by reference could be used by legislators to achieve underhanded ends. At a time, given the limited availability of indices which might have enabled many legislators to track the references, incorporation could be used to further corruption. This was often done through attributions to amending, revising, or occasionally even reviving repealed laws by reference to their titles. ${ }^{15}$ In response, many states added a specific constitutional ban against revising or

\footnotetext{
${ }^{11}$ N.Y. CONST. art. III, $\S 16$. When enacted in 1874 , the ban on incorporation by reference was Article III, $\S 17$ of the State Constitution. It was renumbered by the 1938 Constitutional Convention.

12 Elwyn A. King, State Constitutions Forbidding Incorporation by Reference, 16 B.U. L. REv. 625, 629 (1936). See also John W. Brabner-Smith, Incorporation by Reference and Delegation of Power--Validity of Reference Legislation, 5 GEO. WASH. L. REV. 198, 201 (1937).

${ }^{13}$ For the Erie Railroad War of 1868, see JoHn STEELE Gordon, THE SCARLET WOMAN OF WALL STREET (1988).

${ }^{14}$ For the Tweed Ring of the late 1860s and early 1870s, see ALEXANDER B. CALlOW, THE TWEED RING (1966).

${ }^{15}$ See Brabner-Smith, supra note 12, at 199; People ex rel. Drake v. Mahaney, 13 Mich. 481, 494-95 (1865).
} 
amending laws by referring only to their titles. ${ }^{16} \mathrm{~A}$ few states added to this ban by explicitly ending the practice of incorporation by reference in their constitutions. ${ }^{17}$ New York State only banned legislative incorporation by reference in its constitution. ${ }^{18}$

The New Jersey Supreme Court in 1883 explained the reasoning behind limiting these references. The court found that the bans were intended to prevent deceitful legislation. ${ }^{19}$ "Neither of these provisions was designed to obstruct or embarrass legislation. Both were intended only as a means to secure a fair and intelligent exercise of the law-making power." 20

The point of such constitutional limitations was: to prevent "blind" amendments, to place the proposed act before legislators in a form that enables them to understand the change proposed without reference to a prior act and then to place the enacted statute in the printed laws in a form that enables the public, or more particularly the lawyers, to understand the change without reference to prior legislation. ${ }^{21}$

Ending blind amendments enables the public to have a better understanding of the new law.

But, by the twentieth century, the danger of using incorporation by reference to corrupt legislation had largely waned. Instead, the preexisting "requirements regarding title or amending acts ha[d] become stumbling blocks to legislation. Intended to check certain evils, their operation should have been confined to the narrowest limits, since constitutional impediments of this kind are intrinsically undesirable."22

\footnotetext{
${ }^{16}$ NORMAN SingER, SUTHERLAND STATUTES \& STATUTORY CONSTRUCTION $§ 22: 16$ (7th ed. 2020).

${ }^{17}$ N.J. ConST. art. IV, § 7, para. 5; LA. ConST. art. III, § 15(B); N.D. ConST. art. IV, $\S 13$, cl. 4; OKLA. CONST. art. V, § 57.

${ }^{18}$ Supra note 11 and accompanying text.

${ }^{19} \mathrm{Id}$.

${ }^{20}$ Campbell v. Bd. of Pharmacy, 45 N.J.L. 241, 245 (N.J. 1883), aff'd, 47 N.J.L. 347 (N.J. 1885).

${ }^{21}$ NORMAN Singer, SUTHERLAND STATUTES \& STATUTORY CONSTRUCTION § 22:19 (7th ed. 2020); but cf. Schulz v. N.Y. State Exec., 699 N.E.2d 360, 364 (N.Y. 1998) (finding that the evil of incorporation by reference was to address misapprehension by the legislators and not the voting public).

22 ERnSt FREund, Standards OF AMERICAN LegisLation: AN Estimate OF RESTRICTIVE AND CONSTRUCTIVE FACTORS 285 (1917).
} 
The existence of an obscure, technical ban on incorporation by reference made it problematic for a legislature to determine how best to write legislation.

However, even if we no longer need to be concerned about corrupt use of incorporation by reference, there are other concerns surrounding incorporation by reference. Today, rules and statutes often incorporate voluntary non-governmental or public-private standards. ${ }^{23}$ What if there is little or very limited access to these standards? What if the standards are subject to copyright? $?^{24}$ What if they are expensive to obtain? If the standards are on file in a government agency, are they simple to obtain ${ }^{25}$ Can you obtain the standards easily via the Internet?

To what extent is the legislative body ceding or delegating its sovereignty when it incorporates standards from an industry group or from another legislative body? Can it validly cede its legislative power to another government or non-governmental agency? ${ }^{26}$ Can future standards or future legislative action be incorporated? Must the incorporation refer to standards or laws in place before the legislation was voted on, or can there be "dynamic incorporation" that incorporates future changes in legislation or in standards? ${ }^{27}$

\section{NEW YORK INCORPORATION BY REFERENCE ISSUES}

New York State has managed - without a great deal of forethought - to create a hodgepodge of systems for incorporation by

\footnotetext{
23 Kenneth Abbott \& Duncan Snidal, Strengthening International Regulation Through Transnational New Governance: Overcoming the Orchestration Deficit, 42 VANDERBILT J. TRANSNAT'L L. 501, 506-07 (2009).

${ }^{24}$ See Emily S. Bremer, Incorporation by Reference in an Open-Government Age, 36 HARV. J. L. \& PUB. POL'Y 131, 136 (2013).

${ }^{25}$ What happens when the existence of a pandemic precludes access to the filing?

${ }^{26}$ This would likely run afoul of the New York Constitution which states that, "[t]he legislative power of this state shall be vested in the senate and assembly." N.Y. CONST. art. III, $\S 1$.

27 "State lawmakers frequently incorporate by referencing federal standards, in effect, 'delegating up' the content of future standard setting to the federal government. This form of 'dynamic incorporation' of federal law is commonplace in state legislation as well as in state administrative agency rulemaking." Jim Rossi, Dynamic Incorporation of Federal Law, 77 OHIO ST. L. J. 457, 460 (2016); see also Michael C. Dorf, Dynamic Incorporation of Foreign Law, 157 U. PA. L. REV. PENNUMBRA 103, 104-05 (2008).
} 
reference at different levels of government. Incorporation by reference is technically forbidden for state legislation. But, in reality, New York state legislation is "a thorny road, and the dividing line between what is permissible incorporation by reference and what is not, is oftentimes quite obscure." 28 New York authorizes incorporation by reference for state regulations, but there is a constitutional requirement that the material to be incorporated must be on file..$^{29}$ There are no formal bans at all placed on incorporation by reference in New York local governments. This article will examine each of the methods of handling incorporation by reference and suggest a way of harmonizing all three into a single, cohesive system.

\section{NEW YORK STATE LEGISLATION AND INCORPORATION BY REFERENCE}

After the legislative fight over the Erie Railroad and the end of the Tweed Ring, ${ }^{30}$ and the overwhelming corruption which dominated the governance of both Albany and New York City, Governor John Hoffman proposed a Constitutional Commission to suggest changes to the New York State Constitution in $1872 .{ }^{31}$ Any changes suggested by the Constitutional Commission were to be submitted to the legislature for review. If the legislature approved the constitutional amendments, they were submitted to the people at a referendum. ${ }^{32}$

Given the legacy of the Erie Railroad and Tweed, many of the suggested changes focused on ethics and corruption. ${ }^{33}$ The legislature approved many of these suggestions, and the people approved these changes in an 1874 referendum.

One of the many ethical changes that the State legislature approved was the ban on incorporation by reference in legislation. It passed the Constitutional Commission without any dissent. ${ }^{34}$ On its

\footnotetext{
${ }^{28}$ Cnty. of Nassau v. Bennett, 231 N.Y.S.2d 766, 773 (Sup. Ct. 1962).

${ }^{29}$ N.Y. CONST. art. IV, § 8; see also People v. Cull, 176 N.E.2d 495 (N.Y. 1961).

${ }^{30}$ See GORDON, supra note 13; CALlOW, supra note 14.

${ }^{31}$ The Governor's Message, N.Y. TIMES, Jan. 3, 1872, at 4.

32 These would be treated in the same manner as Constitutional amendments recommended by the legislature.

${ }^{33}$ The State Constitution, N.Y. TIMES, May 7, 1874.

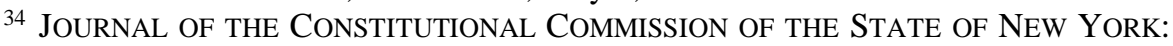
BEGUN AND HELD IN THE COMMON COUNCIL CHAMBER, IN THE CITY OF ALBANY, ON THE 4TH DAY OF DECEMBER, 1872-73 172 (1873). No statement of legislative intent
} 
face, "literally construing this provision, it is clear that the section would make all referential legislation impossible." 35

Yet, despite the broad language of the ban on incorporation by reference, New York courts have consistently given the provision an extremely narrow construction. In 1906, New York State constitutional historian Charles Z. Lincoln wrote, "[S]o far as I have observed, statutes which have been challenged as invalid under it have all been sustained ... . [T] he provision does not now seem to have much practical significance, and apparently it is not now considered a serious restraint on legislative power." ${ }^{36}$

The Court of Appeals had largely viewed the ban on incorporation of reference as being akin to the future informal basketball directive of "no harm, no foul." Thus, the court would only find that a constitutional violation occurred when legislators and/or the public might be confused or ignorant of the reference. ${ }^{37}$ The court focused on transparency of the legislative process. The court stated in 1876 ,

The evil in view in adopting this provision of the Constitution, was the incorporating into acts of the legislature by reference to other statutes, of clauses and provisions of which the legislators might be ignorant, and which affecting public or private interests in a manner and to an extent not disclosed upon the face of the act, a bill might become a law, which would not receive the sanction of the legislature if fully understood. ${ }^{38}$

In a subsequent case, the court added,

has been found. ROBERT Allan CARTER, NeW YORK STATE CONSTITUTION: SOURCES OF Legislative INTENT 29 (2d. ed. 2001). See also 1 NeW York State LEGiSlature, REVISED RECORD OF THE CONSTITUTIONAL CONVENTION OF THE STATE OF NEW YoRK: APRIL SiXTH TO SEPTEMBER TENTH, 1915826 (1916).

355 ACAdemy of Political Science, The Revision of the State Constitution Part I 106 (1914); 7 NeW York State Constitutional CONVENTION Committee, Problems Relating to Legislative Organization and Power 73 (1938).

${ }^{36}$ Charles Z. LinColn, 4 CONSTitutional History OF NEW YorK 411 (1906).

3797 N.Y. JUR. 2D Statutes $§ 26$ (2021).

${ }^{38}$ People ex rel. Bd. of Comm'rs of Wash. Park v. Banks, 67 N.Y. 568, 575-76 (1876). 
The framers of this provision could never have intended to introduce into our statute law such elements of confusion and uncertainty. Their purpose was to require bills introduced in the legislature to be presented in such form, and their essential provisions expressed in such language, that the effect of the proposed enactment might be understood by legislators of reasonable intelligence. To carry out this intention, it is not necessary to give to the amendment a literal construction. ${ }^{39}$

Again, only statutes that both violate the letter and the spirit of this Constitutional provision are judged to be invalid.

The one substantive effect of the provision in the New York Constitution was that it prevented the revival of repealed or lapsed statutes through incorporation by reference. The Second Department of the Appellate Division, in the 1876 case of Blauvelt v. Nyack, ${ }^{40}$ found that prior to the constitutional amendment banning incorporation by reference (which first took effect in 1875) there was no provision in New York law that prevented the revival of repealed statutes by a reference to their enactment. In 1874, a law on the incorporation of villages was enacted, which revived certain 1846 provisions that had been previously repealed. ${ }^{41}$ The court upheld the revival of the 1846 statute by stating that, "[t]here was then no constitutional prohibition against that method of legislation, and it was in common use. The fact that an amendment to the Constitution was necessary to make it illegal

\footnotetext{
${ }^{39}$ People ex rel. Everson v. Lorillard, 31 N.E. 1011, 1013 (1892). Cf. The legislature also did not seem to have any antipathy towards the general practice of incorporation by reference in wills. "No suggestion that it was regarded as a mischief or inconvenience by the legislature can be found in the legislative journal, nor in the report of the debates in the Albany Argus, and no such suggestion is contained anywhere in the Revisers' Notes." Current Topics, 59 AlB. L. J. 443, 451 (1899). See also Tonnele v. Hall, 4 N.Y. 140 (1850).

4016 N.Y. Sup. Ct. 153 (1876).

${ }^{41}$ Law of 1847 , ch. $628, \S 32-33$. The relevant portion of the law read, All other general acts and laws of this State for the general incorporation of villages are hereby repealed, as to the future incorporation of villages, except sections ninety and ninety-one of chapter four hundred and twenty-six of the laws of eighteen hundred and forty- seven, which sections shall form a part of this act.

$I d$. at $\S 32$.
} 
shows that previous to such amendment it was legal." 42 Thus, the one substantive achievement of the ban on incorporation by reference was to make sure that law could not be revived by reference. ${ }^{43}$

At the 1915 New York State Constitutional Convention, there was a proposal to repeal much of the ban on incorporation by reference. Delegate Richard Smith, while believing there should continue to be a ban on reviving repealed statutes by reference, believed that the incorporation by reference provision served no real purpose and had been condemned without exception by the New York courts. $\mathrm{He}$ stated,

It stands here as a bugbear every time we draft a statute, to determine whether a reference to what we believe to be procedure or administrative detail will be held by the court to be procedure or administrative detail, or whether the court will say that it affects some substantive branch of the law. ${ }^{44}$

While other delegates agreed that the incorporation by reference provision was constructed very narrowly, ${ }^{45}$ they could not agree on the wisdom of Delegate Smith's proposed amendment, and the Convention recommitted his proposal to the appropriate committee. ${ }^{46}$

Nonetheless, in 1935, sixty years after the enactment of the ban on incorporation by reference, the Court of Appeals finally struck down a law for violating this provision. In Darweger $v$. Staats, ${ }^{47}$ the court had to determine the constitutionality of the 1933 State Recovery Act. ${ }^{48}$ The State Recovery Act, passed in the midst of the Great

${ }^{42}$ Blauvelt, 16 N.Y. Sup. Ct. at 154-55.

${ }^{43}$ See generally New York State Constitutional Convention CommitTeE, supra note 35, at 73 .

${ }^{44}$ New York State LegisLature, supra note 34, at 827.

${ }^{45}$ Delegate Edgar Brackett said, "But it comes finally that the courts have practically, and I think I can say entirely, ignored the whole provision." NEW YORK STATE LEGISLATURE, supra note 34 , at 830.

${ }^{46}$ New York STATE LegisLATURe, supra note 34, at 831.

${ }^{47} 196$ N.E. 61 (N.Y. 1935).

${ }^{48}$ Law of 1933, ch. 781. The legislation was generally known as the Schackno Act, after its sponsor State Senator Henry Schakno. It was also known as the State NRA, after the federal National Recovery Act. See Code Violators Warned State Will Prosecute, CITY NRA Committee Calls Attention to Schackno Act, N.Y. HERALD TRIB., Sept. 16, 1933, at 4. The federal NRA was found unconstitutional later that year by Schechter Poultry Corp. v. United States, 295 U.S. 495 (1935). 
Depression, regulated an assortment of commodity prices. ${ }^{49}$ It fixed the prices by having the industrial fair competition codes determined by the National Recovery Administration apply to intrastate businesses. ${ }^{50}$ An intrastate business that violated the federal code was guilty of a state misdemeanor. ${ }^{51}$ Thus, the case presented an issue where the state had incorporated by reference a potentially future federal regulation. Darweger, an intrastate coal dealer who wished to charge a lower price lower than the fixed price under federal industrial code, challenged the constitutionality of the state law..$^{52}$

In a 4-3 decision by Chief Judge Crane, the Court of Appeals agreed with Darweger. The State Recovery Act violated the state constitution by improperly delegating state sovereignty to the federal government since the law "is a mere shell, leaving to national bodies or officials the power to make the laws of New York State." ${ }^{53}$ Similarly, the constitutional ban on incorporation by reference was violated. Chief Judge Crane wrote, "Surely an act which provided that any regulation of Congress hereafter made when filed with the Secretary of State would be enforceable in this state, and a violation thereof would be a misdemeanor, would be a violation of the spirit and letter of this our constitutional provision." 54

Judge Lehman argued, for a three-judge minority, that there was no delegation of state sovereignty. ${ }^{55}$ There was also no violation of the ban on incorporation by reference. ${ }^{56}$ According to Judge Lehman, the ban, on its face, only applied to "any existing law." 57 Since the reference in the legislation in question was to a rule, not a law, there was no violation of the constitutional provision. ${ }^{58}$

\footnotetext{
${ }^{49}$ Darweger, 196 N.E. at 64.

${ }^{50} \mathrm{Id}$.

${ }^{51} \mathrm{Id}$. at 65.

$52 \mathrm{Id}$. at 64.

${ }^{53} \mathrm{Id}$. at 66.

${ }^{54} \mathrm{Id}$. at 67.

${ }^{55} \mathrm{Id}$. at 69-71.

${ }^{56} \mathrm{Id}$. at 72 .

${ }^{57} \mathrm{Id}$.

${ }^{58} I d$. There was no discussion in either of the opinions of the fact that the price controls were not in effect at the time the state legislation was enacted. This was an early example of dynamic incorporation by reference, which encompasses a future standard not in effect at the time of enactment. Dynamic incorporation is to be contrasted to static incorporation, where the referenced material is fixed because it is in existence at the time of the statutory enactment.
} 
Since the decision in Darweger, little has changed in the way that the New York courts have treated incorporation by reference in statutes. The vast majority of challenged laws are upheld, with only a small minority of laws found invalid. ${ }^{59}$ The rationales used for upholding the challenged statutes remain essentially the same as those used in the cases before Darweger. Curative statutes were considered immune from the ban on incorporation by reference. ${ }^{60}$ Statutes amending existing provisions were not subjected to the constitutional ban. ${ }^{61}$ Courts similarly upheld the validity of procedural statutes. ${ }^{62}$ Only non-transparent statutes, where the effect of the language of the

[S]tate cases also confirm the crucial importance of the distinction between static and dynamic incorporation. Some state cases note that incorporation of future federal law would present a different question; others, where necessary, carefully construe state law so that it effects only a static incorporation; some state cases actually hold dynamic incorporation of federal law to be unconstitutional.

Jonathan R. Siegel, The Use of Legislative History in a System of Separated Powers, 53 VAND. L. REV. 1457, 1486 (2000); see also Cindy G. Buys \& William Isasi, An 'Authoritative' Statement of Administrative Action: A Useful Political Invention Or A Violation of the Separation Of Powers Doctrine?, 7 N.Y.U. J. LEGIS. \& PUB. POL'Y 73, 101-02 (2003 \& 2004).

59 See Med. Soc'y v. State Dep't of Health, 633 N.E.2d 468 (N.Y. 1994); Consolidated Edison Co. v. Moore, 98 N.Y.S.2d 973 (App. Div. 1950).

${ }^{60}$ Tartaglia v. McClaughlin, 79 N.E.2d 809, 811 (1948); Cerro v. Town of Kingsbury, 672 N.Y.S. 953, 955 (Sup. Ct. 1998). See also Town of Islip v. Cuomo, 541 N.Y.S.2d 829, 831 (App. Div. 1989).

It is therefore apparent that the terms of N.Y. Constitution, article III, $\S$ 16, construed literally, do not apply ... ECL 27-0704 does not incorporate a pre-existing 'law,' and thus does not violate N.Y. Constitution, article III, $\S 16$, unless, by 'liberal' judicial interpretation its scope were expanded beyond the limits to which, by the clear and unambiguous definition of its terms, it is confined. A review of the relevant precedent indicates that far from indulging in such a 'liberal' interpretation, the courts have exhibited a pragmatic and relatively restrictive approach in applying this provision to particular cases. Only those statutes which violate both the letter and the spirit of this constitutional provision have been invalidated; ECL 27-0704 violates neither.

Id. Curative statutes are "designed to remedy specific defects in proceedings already prosecuted.” N.Y. STAT. § 54(b) (McKinney 2021); see also Garal Wholesalers Ltd. V. Miller Brewing Co. 751 N.Y.S.2d 679 (Sup. Ct. 2002).

${ }^{61}$ See Metro. Package Store Ass'n, Inc. v. Koch, 457 N.Y.S.2d 481, 486-87 (App. Div. 1982); 97 N.Y. JUR. 2D Statutes $§ 28$ (2021).

${ }^{62}$ See Burke v. Kern, 38 N.E.2d 500, 505 (N.Y. 1941); Humann v. Rivera, 71 N.Y.S.2d 321, 325 (App. Div. 1947); Cnty. of Nassau v. Bennett, 231 N.Y.S.2d 766, 772 (Sup. Ct. 1962). 
enactment was not disclosed on its face, would be subject to the ban on incorporation by reference. ${ }^{63}$

Nonetheless, there are a small number of cases holding that the ban on incorporation by reference was violated. Three years after Darweger, a unanimous Court of Appeals in Becker v. Eisner ${ }^{64}$ found that a statute was too vague on its face, and therefore violated the constitutional ban. By reference, the statute in question applied the appointment, suspension, reinstatement, dismissal, and probationary procedures that governed hiring by the New York City Board of Education (affecting primary and secondary schools) to the New York City Board of Higher Education (affecting post-secondary schools). ${ }^{65}$ The court found that the reference to "all laws" governing the Board of Education was "entirely too vague." 66 The judges further reasoned, "[t]o permit it to pass as proper legislation would in effect nullify the Constitution." 67 The court found that the vagueness of the reference would cause many of the problems that highlighted the reasoning behind the ban on incorporation by reference. ${ }^{68}$ The language of the reference was "deceptive," and the court held that no one could tell which exact laws were to be applied by the Board of Higher Education. ${ }^{69}$

In Levine v. O'Connell, ${ }^{70}$ the Appellate Division reviewed a statute that granted the power to mandate price-fixing to the State

${ }^{63}$ Med. Soc. of State of N.Y. v. State Dep't of Health, 633 N.E.2d 468, 470-71 (N.Y. 1994).

\begin{abstract}
The purpose of the constitutional prohibition against incorporation by reference is to prevent the Legislature from incorporating into its acts the provisions of other statutes or regulations which affect public or private interests in ways not disclosed upon the face of the act, and which would not have received the sanction of the Legislature if fully understood by it.
\end{abstract}

Id. See also Schulz v. N.Y. State Exec., 699 N.E.2d 360, 364 (N.Y. 1998); City of New York v. State, 357 N.E.2d 988, 998 (Gabrielli, J. dissenting) (N.Y. 1976); Concerned Home Care Providers, Inc. v. State, 969 N.Y.S.2d 210, 214 (App. Div. 2013); Delese v. Tax Appeals Tribunal of State of New York, 771 N.Y.S.2d 191, 194 (App. Div. 2004).

6413 N.E.2d 747 (N.Y. 1938).

${ }^{65}$ Id. at 749 (N.Y. 1938). See Law of 1935, ch. 873.

${ }^{66}$ Becker, 13 N.E.2d at 750.

${ }^{67} \mathrm{Id}$.

${ }^{68} \mathrm{Id}$.

${ }^{69} \mathrm{Id}$.

${ }^{70} 88$ N.Y.S.2d 672 (App. Div. 1949), aff'd, 300 N.Y. 658 (1950). 
Liquor Authority. ${ }^{71}$ The legislation gave the Liquor Authority pricefixing authority by incorporating by reference the Fair Trade Law provisions in the State's General Business Law into the Alcoholic Beverage Control Law. ${ }^{72}$ The court ruled that the power granted by the legislature to the Liquor Authority was excessive and that the legislature had improperly delegated its lawmaking authority to the Liquor Authority. ${ }^{73}$ Furthermore, the court found that this incorporation of the Fair Trade Law

would violate the spirit of this provision of the Constitution for the significant reason that the Fair Trade Law was adopted for a different purpose, viz., to enable the owner of a brand name to protect such name by fixing resale prices at its own election, ... whereas it is incorporated in the Alcoholic Beverage Control Law for the purpose of facilitating the enforcement of the liquor laws. ${ }^{74}$

Since the legislature did not truly realize the extent of this incorporation, the court believed that this was a violation of the constitutional ban on incorporation by reference. ${ }^{75}$ The Court of Appeals affirmed the Appellate Division's decision without issuing an opinion. ${ }^{76}$

Since Darweger, one trial court has also used the ban on incorporation by reference to strike down legislation. In People $v$. Mazzie ${ }^{77}$ the New York County Supreme Court reviewed the validity of a law providing mandatory minimum prison sentences for anyone convicted of a felony, if the felon was convicted of another felony in any jurisdiction within the past ten years. ${ }^{78}$ The court found this was a clear violation of Art III, $\S 16$. The court stated that, "it is difficult to imagine an incorporation more sweeping than the adoption ... of

${ }^{71} I d$. at 675 .

${ }^{72} \mathrm{Id}$. at $677-78$.

${ }^{73} \mathrm{Id}$. at 677.

${ }^{74} \mathrm{Id}$. at 678 .

${ }^{75} \mathrm{Id}$. at $678-79$.

${ }^{76}$ Levine v. O'Connell, 300 N.Y. 658, 660 (N.Y. 1950).

${ }^{77}$ People v. Mazzie, 358 N.Y.S. 307 (Sup. Ct. 1974), abrogated by People v. Parker, 359 N.E.2d 348 (N.Y. 1976).

${ }^{78}$ Law of 1973, ch. 276-77. This was later incorporated in N.Y. PENAL L. $§ 70.06$. Mazzie, 358 N.Y.S. at 309. 
the criminal laws of every federal, state, local and even foreign jurisdiction. The Legislature could not possibly have been aware, nor could it have intended" that people convicted of minor offenses that were felonies in other states would be treated as repeat offenders. ${ }^{79}$ Given its belief that the legislature was unaware of the consequences of the incorporation, the court held " $[t]$ he incorporation of them into our penalty structure cannot constitutionally be tolerated." $" 80$

While Mazzie was not appealed, a case involving mandatory minimum sentences did reach the Court of Appeals. In Peoplev. Parker ${ }^{81}$ the court gave the incorporation by reference argument short shrift. New York's mandatory minimum sentence statute did not incorporate any felony statutes outside of New York State. The law simply authorized courts to use "out-of-state, felonies as predicates in order to determine a defendant's length of punishment. "The foreign conviction involves the application of foreign law but does not in any way make that law applicable in New York." ${ }^{82}$ Thus, there was no violation of Article III, $\S 16$.

Accordingly, New York has a constitutional ban on incorporation by reference that is rarely invoked but can occasionally be utilized to invalidate legislation. ${ }^{83}$ It works much like an ancient land mine which can sporadically crop up and seemingly blow-up legislation whenever a court subjectively determines that the incorporation could have been confusing to the legislature.

${ }^{79}$ Id. at 311. See Marcia Chambers, Sentencing Law Ruled Improper, N.Y. TIMES, July 26, 1974, at 68 .

${ }^{80}$ Mazzie, 358 N.Y.S. at 312.

81359 N.E.2d 348 (N.Y. 1976).

${ }^{82} I d$. at 352 .

${ }^{83}$ In addition to the cases cited, Governor Rockefeller vetoed a bill in 1959 that would have given the Nassau County Board of Supervisors the same power over contracts that may be conferred generally upon counties or officers, boards or agencies of counties by the general municipal law. Darweger v. Staats, 196 N.E. 61, 70 (N.Y. 1935). The Governor vetoed the bill based on the Attorney General's recommendation that the bill violated the ban on incorporation by reference. NELSON A. Rockefeller, Public PAPers of Nelson A. Rockefeller 282 (1959). The Attorney General also found that a bill that incorporated by reference a schedule contained in a legislative committee report was a violation of the provision banning incorporation by reference. Opinions, 1916 NY Att'y Gen. Rep. \& Op. 325, 347348 (1916). 


\section{OTHER Limits ON THE CONSTITUTIONAL BAN ON INCORPORATION BY REFERENCE}

The haphazard nature of the constitutional ban on incorporation by reference is further enhanced by other provisions of the state constitution, most notably Article III, $\S 21$. This section exempts bills "which shall be recommended to the legislature by commissioners or any public agency appointed or directed pursuant to law to prepare revisions, consolidations or compilations of statutes" 84 from three of the restrictions in the State Constitution. The ban on legislative incorporation by reference is one of the restrictions that does not apply to bills recommended by commissioners or public agencies. ${ }^{85}$

This exemption dates from the same 1872 Constitutional Commission that produced the ban on incorporation by reference. At the time of the passage of these provisions, Ch. 33, L. 1870 had created a commission which had been appointed by the legislature "to revise the general laws of the state." 86 This commission had not completed its work at the time that the Constitutional Commission was preparing its recommendations.

After the Constitutional Commission adopted sections relating to special legislation, it concluded that in view of the scope of the work of the revision commission, its bills should not be restricted by the amendments proposed by the Constitutional Commission but that the revision commission should present bills in such manner as it was authorized. ${ }^{87}$

At the 1938 State Constitutional Convention, Section 21 was amended to expand the scope of the exemptions. Besides applying to "commissioners" appointed by the legislature to revise the laws, the exemption was extended to "any public agency appointed or directed" by law "to prepare revisions, consolidations or compilations of

\footnotetext{
${ }^{84}$ N.Y. CONST., art. III, $\S 21$.

85 The others are article III, section 15, which requires that private or local bills can only embrace one subject, and the ban on certain private and special legislation in article III, section 17.

862 Charles Z. Lincoln, CONSTITUTIONAl History OF NEW YORK 505 (1906).

${ }^{87}$ N.Y. State Const. CONVEntion COMM., PROBlems Relating To LEGislative ORGANIZATION AND POWER 101 (1938).
} 
statutes." 88 Convention delegate Abbot Lowe Moffat commented, "I think the limitation that the exceptions ... should be restricted to those who are officially directed to prepare such compilations or revisions." $" 89$

While there are only a handful of decisions that interpret the 1938 amendment to Section 21, those decisions have interpreted the "any public agency" exemption broadly. In Conrad v. Home \& Auto Loan Company, ${ }^{90}$ the issue presented was whether legislation ran afoul of the prohibition on incorporation of reference.

In Conrad, the legislation was proposed by the State Banking Department. ${ }^{91}$ The court found that the Banking Department "has been directed by the Legislature to submit proposals for any amendment to the Banking Law which it deems desirable. The proscription of article III, section 16, therefore, does not apply to the incorporation of the Federal act and regulations." ${ }^{92}$ Thus, legislation proposed by a state agency empowered to recommend legislation qualified under section 21 as a public agency directed to prepare revisions of statutes.

The trial court in People v. Graff ${ }^{33}$ found that bills recommended by the Temporary State Commission to Evaluate the Drug Laws qualified for the Section 21 exemption. While the Temporary State Commission was hardly a law revision commission, its legislative recommendations qualified for the exemption "as any bill which shall be recommended to the legislature by commissioners or any public agency." ${ }^{44}$ It almost appears that any commission created for a specific purpose would overcome the limitations of Article III, Section 17 of the Constitution.

In People v. Kavanaugh,${ }^{95}$ the court ruled that the constitutional provision banning incorporation by reference in statutes did not apply

\footnotetext{
${ }^{88}$ N.Y. CONST. of 1938, art. III, $\S 21$ (1938); see also CARTER, supra note 34, at 31. ${ }^{89}$ Revised Record of the Constitutional Convention of the State of New York, April Fifth to August Twenty-Sixth, Tuesday July 19, 1938, 1158 (1938).

90385 N.Y.S.2d 979 (App. Div. 1976).

${ }^{91} I d$. at 983.

${ }^{92} \mathrm{Id}$.

93359 N.Y.S.2d 976 (Sup. Ct. 1974).

${ }^{94}$ Id. at 978-79; see also Opinions, 1949 N.Y. Att'y Gen. Rep. \& Op. 1 (1949) (“The Judicial Council comes within the provisions of Article III, Section 21 of the New York Constitution, and a recommendation by it of an amendment to the laws with respect to the jury system.").

${ }^{95} 507$ N.Y.S.2d 952 (Dist. Ct. 1986).
} 
to agency rulemaking. ${ }^{96}$ An agency's rulemaking activity - where it proposed and enacted the rule - would qualify for the Section 21 exemption because the agency's activities would show that it was a "public agenc[y]" empowered to prepare such revisions. ${ }^{97}$ Accordingly, an agency's legislative recommendations can provide an exemption under section 21.

In current day New York State, almost all major policy issues are decided through the Governor's executive budget. ${ }^{98}$ It is plausible that the executive budget would qualify for the Section 21 exemption.

Applying the Section 21 decisions to the annual state budget, the New York Constitution requires the governor to submit an annual budget.

The governor shall submit to the legislature a budget containing a complete plan of expenditures proposed to be made before the close of the ensuing fiscal year and all moneys and revenues estimated to be available therefor, together with an explanation of the basis of such estimates and recommendations as to proposed legislation, if any, which the governor may deem necessary. ${ }^{99}$

Additionally, "[a]t the time of submitting the budget to the legislature the governor shall submit a bill or bills containing all the proposed appropriations and reappropriations included in the budget and the proposed legislation, if any, recommended therein." 100 The governor as part of the budget process "may . . . amend or supplement the budget and submit amendments to any bills submitted by him or her or submit supplemental bills." 101

${ }^{96} I d$. at 955.

${ }_{9797}$ Id.

${ }^{98}$ See Alessandra Biaggi \& Richard Gottfried, Returning Power to the People by Rebalancing the State Budget Process, GOTHAM GAZETTE (July 22, 2020), https://www.gothamgazette.com/opinion/9616-power-to-the-people-new-yorkstate-budget-process; Richard Brodsky, Of All State Government's Flaws, This Is the Most Dangerous, ALBANY TIMES UNION, https://www.timesunion.com/opinion/article/Of-all-state-government-s-flaws-thisis-the-most-13512591.php (Jan 7, 2019, 7:03 AM).

${ }^{99}$ N.Y. CONST. art. VII, § 2.

${ }^{100}$ N.Y. CONST. art. VII, $\$ 3$.

${ }^{101} I d$. 
The State Finance Law further requires a budget "submitted annually by the governor to the legislature, in accordance with article seven of the constitution." 102 Section 24 of the State Finance Law adds that "[t]he budget submitted annually by the governor shall be simultaneously accompanied by a bill or bills for all proposed appropriations and reappropriations and for the proposed measures of taxation or other legislation, if any, recommended therein." ${ }^{103}$ Given the explicit directives in the State Constitution and the State Finance Law, the budget legislation submitted by the governor can be viewed as legislation recommended by a public agency directed pursuant to law to prepare revisions, and accordingly subject to the exemption provided by section 21 .

Thus, not only have the courts given a very narrow construction to the ban on incorporation by reference, but the State Constitution exempts a considerable number of bills from even the limited scrutiny of the incorporation by reference ban.

In addition to the exemption from incorporation by reference scrutiny in section 21, the New York State Constitution has created an exemption from incorporation by reference for the federal income tax laws. Notwithstanding the ban on incorporation by reference in the Constitution,

[t]he legislature, in any law imposing a tax or taxes on, in respect to or measured by income, may define the income on, in respect to or by which such tax or taxes are imposed or measured, by reference to any provision of the laws of the United States as the same may be or become effective at any time or from time to time. ${ }^{104}$

This provision authorized the legislature to incorporate by reference the federal income tax laws. ${ }^{105}$ It does not mandate that the legislature

\footnotetext{
${ }^{102}$ N.Y. State Fin. L. § 22 (McKinney 2015).

${ }^{103}$ N.Y. FIN. L. § 24(1) (McKinney 2021).

${ }^{104}$ N.Y. CONST., art. III, $\S 22$.

${ }^{105}$ It does not authorize the incorporation by reference of the federal estate tax laws. See Charles E. Heming, New York State Bar Association Tax Section, 44 N.Y. StATE BAR J. 339, 342 (1972); see also Peter Miller, Proposal for a Federally-Based New York Personal Income Tax, 13 TAX L. Rev. 183 (1958); Edward R. Hayes, Effect of Changes in Legislation Incorporated by Reference, 43 MinN. L. REV. 89, 97-98 (1958). "Thus, the state's administrative problems may be reduced and perhaps a smaller staff needed to enforce the state's law." NELSON A. RoCKefEller. PUblic PAPERS OF NELSON A. ROCKEFELler 1007 (1959).
} 
incorporate federal income tax laws. That is left to the legislature; but, the legislature can use dynamic incorporation so it can incorporate federal income tax amendments that are made after the adoption of the incorporation legislation. ${ }^{106}$

The New York State Bar Association and local bar associations provided the impetus for the incorporation of the federal income tax laws. The constitutional amendment authorizing incorporation by reference was passed by the electorate in 1959, ${ }^{107}$ and the State Bar Association stated it had "approved a proposed amendment to the State Constitution authorizing the incorporation by reference of the Federal definition of income for the purposes of New York State income taxation." 108 Legislation was passed in 1960 that conformed the New York State income tax definitions to federal definitions. ${ }^{109}$

Section 22 of Article III specifically authorizes dynamic incorporation of federal income tax provisions. Cases across the states differ significantly as to whether dynamic incorporation of legislation is permitted, ${ }^{110}$ but twelve states have provisions in their constitutions authorizing dynamic incorporation of federal tax law. ${ }^{111}$ Arguably, placing the authorization for dynamic incorporation into the state constitution would shield New York's income tax incorporation by reference from the requirement of Article III, Section 1 of the

Governor Rockefeller, in 1959, similarly said that incorporation by reference "would make possible the shortening and simplification of New York's personal income tax forms and reduce from hours to minutes the time required for preparation of State tax returns. Id. "It would also facilitate and reduce the cost of processing the returns by the Department of Taxation and Finance." Id.

${ }^{106}$ ROCKEFELLER, supra note 105.

${ }^{107} 1958$ Senate Intro. 2017, Print 3303; 1959 Senate Intro. 12, Print 12; see generally CARTER, supra note 34, at 32.

108 Chauncey Belknap, Executive Committee Report for 1959, 32 N.Y. STATE BAR BULl. 7, 8 (1960).

${ }^{109}$ Law of 1960, ch. 563. The legislation declared

that the adoption by this state for its personal income tax purposes of the provisions of the laws of the United States relating to the determination of income for federal income tax purposes will (1) simplify preparation of state income tax returns by taxpayers, (2) improve enforcement of the state income tax through better use of information obtained from federal income tax audits, and (3) aid interpretation of the state tax law through increased use of federal judicial and administrative determinations and precedents.

See N.Y. TAX L. §§ 291, 616 (McKinney 2021).

${ }^{110}$ See Dorf, supra note 27, at 108-10 (providing a list of the individual states).

${ }^{111}$ Dorf, supra note 27, at 109-10. 
constitution that vests the State's legislative power in the Senate and the Assembly. ${ }^{12}$

Besides the narrow construction of the State's general ban on incorporation by reference, the ban is further limited by the exemptions for (1) bills that are "recommended to the legislature by commissioners or any public agency appointed or directed pursuant to law to prepare revisions, consolidations or compilations of statutes" 113 and (2) for federal income tax definitions. ${ }^{114}$ Given the court decisions analyzing legislative incorporation by reference, there is actually not much substance left in the purported statutory ban on incorporation by reference.

\section{INCORPORATION BY REFERENCE IN STATE REGULATIONS}

On its face, the Article III, Section 16 ban on reference by incorporation applies to legislation. The language of the section, embodied in a statute aimed at legislation, refers specifically to "acts." 115 The term "act" in the constitution only seems to be used for bills that have been passed by the legislature. ${ }^{116}$ There is absolutely no indication that it would apply to a rule or regulation.

One court has specifically noted that Article III, Section 16 does not apply to rules. ${ }^{117}$ In People v. Kavanaugh, the court stated, "Further, the proscription of Article III, Section 16, of the N.Y.S. Constitution applies to statutes and not to rules or regulations. The purpose of the provision is to prevent the incorporation into legislative enactments ...."118

\footnotetext{
${ }^{112}$ Even though the specific authorization in Article III, Section 22, might seem to counter the general language of Article III, Section 1, isn't the grant of sovereignty to the legislature such an essential part and function of State government, that any grant of dynamic incorporation should be viewed negatively?

${ }^{113}$ N.Y. CONST. art. III, § 21.

${ }^{114}$ N.Y. CONST. art. III, $\S 22$.

115 N.Y. STAT. § 1 (McKinney 2021),

${ }^{116}$ See N.Y. ConsT. art. III, $\S \S 16,23$.

${ }^{117}$ People v. Kavanaugh, 507 N.Y.S.2d 952, 955 (Dist. Ct. 1986).

${ }^{118} I d$. at 955 . In that case, the court added that another reason why Article III, section 16 only applied to legislative acts was that an agency's rules would be protected from the incorporation by reference ban by Article III, section 21's exemption for recommendations by commissioners or public agencies. $I d$.
} 
Rules and regulations are governed by Article IV, Section 8 of the New York State Constitution. ${ }^{119}$ The purpose of the rule was to establish a central office where the rules of state agencies could be housed to provide the public with notice of the rules. ${ }^{20}$ The provision states, "No rule or regulation made by any state department, board, bureau, officer, authority or commission, except such as relates to the organization or internal management of a state department, board, bureau, authority or commission shall be effective until it is filed in the office of the department of state." ${ }^{21}$ The language was added by the 1938 Constitutional Convention. It was Delegate George Fearon ${ }^{122}$ who believed that the constitutional filing requirement for rules and regulations was a necessity for the public. ${ }^{123}$ The people of the state needed to have actual notice of the requirements imposed on them by State agencies and the filings needed to be placed in a single common location. Delegate Fearon explained that

[t]he evil of the situation that we are desiring to correct lies in the fact that at the present time, with a few very notable exceptions, there are no public rules or regulations of the departments of which the public generally has any notice. The bill ... will guarantee to the people of this State who do business with the departments and bureaus that they can have actual notice of the rules and regulations. ${ }^{124}$

The proposal passed the convention by a vote of 149 to $1 .{ }^{125}$ It has remained basically unchanged since its passage in 1938 .

There have been two major Court of Appeals cases interpreting Article IV, Section 8. In People v. Cull, ${ }^{126}$ the court defined a rule or regulation broadly in order to include all quasi-legislative actions taken by an agency. ${ }^{127}$ Thus, an order issued by the State Traffic

\footnotetext{
${ }^{119}$ N.Y. CONST. art. IV, $\S 8$.

${ }^{120}$ People v. Cull 176 N.E.2d 495, 497-98 (N.Y. 1961).

${ }^{121}$ N.Y. CONST. art IV, $\S 8$.

${ }^{122}$ Fearon was a long-time legislator and had served as both the majority leader and the minority leader of the State Senate.

1232 REVISED ReCord of THE CONSTITUTIONAL CONVENTION OF THE STATE OF NeW YoRK, APRIL FIFTH TO AUGUST TwENTY-SIXTH 1429 (1938).

${ }^{124} \mathrm{Id}$.

${ }^{125} \mathrm{Id}$. at 1434 .

${ }^{126} 176$ N.E.2d 495 (N.Y. 1961).

${ }^{127}$ Id. at 497.
} 
Commission was a "rule" that had to be filed with the Secretary of State in order to be effective. Judge Fuld, for a unanimous court, wrote,

We know that underlying the provision was the desire to have all rules and regulations affecting the public filed in one, easily available, central place. We should not strive to read exceptions into the section or construe it so as to permit the official in charge of the bureau, commission or authority to avoid the necessity of filing by attaching the label 'order' or 'statement of policy' or some other term to what is essentially a rule or regulation. ${ }^{128}$

In that manner, the Court of Appeals determined that a state agency could not evade the requirements of Article IV, Section 8 by terming a quasi-legislative action as something other than a rule or regulation.

The other major Court of Appeals case was New York State Coalition of Public Employers v. New York State Department of Labor. ${ }^{129}$ Acting pursuant to a direction in the State Labor Law, the State Department of Labor, in a rule, incorporated by reference all the health and safety standards promulgated under the United States Occupational Safety and Health Act ("OSHA"). ${ }^{130}$ In a memorandum decision, the court found that this incorporation by reference violated Article IV, Section $8 .{ }^{131}$ The decision in Cull mandated that all quasilegislative actions must be filed with the Secretary of State. ${ }^{132}$ Meanwhile, in Coalition of Public Employers, the OSHA regulations had not been filed. ${ }^{133}$

In 1984, acting on the decision in Coalition of Public Employers, the legislature amended section 102 of the Executive Law to provide guidance for materials that agencies incorporated by reference through their rules and regulations. ${ }^{134}$ If a rule contains incorporated materials, it needed to be filed with the New York Secretary of State and the filing had to contain

\footnotetext{
${ }^{128} I d$. at 498.

129457 N.E.2d 785 (N.Y. 1983).

${ }^{130} I d$. at 786.

${ }^{131} \mathrm{Id}$.

${ }^{132}$ People v. Cull, 176 N.E.2d 495, 497 (N.Y. 1961).

${ }_{133}$ Coalition of Public Employers, 457 N.E.2d at 786.

${ }^{134}$ Law of 1984, ch. 941.
} 
a precise identification of such material, including but not limited to: applicable titles, dates, editions, page numbers, section numbers, and authors, the names and addresses of the publisher from whom a copy may be obtained, and the designated office or offices of the adopting agency at which such material is available for public inspection and copying. ${ }^{135}$

Additionally, the agency filing the rule that contained incorporated materials from sources of state law had to make the incorporated material available at the "legislative library and within each judicial department of the state, one court law library designated by the chief administrator of the courts." 136 However, starting in 2011, incorporated materials no longer need to be filed at the legislative library and law libraries if they are "readily available without charge" on the internet. ${ }^{137}$

There are decisions which indicate that under $\mathrm{Cull}$ and Coalition of Public Employers - even without resort to section 102 of the Executive Law - incorporated materials need to be on file with the New York Secretary of State. In People v. Attco Metals Industries, Inc., ${ }^{138}$ the Court of Appeals specifically required "that before any rule incorporation by reference can be constitutionally acceptable pursuant to Article IV, Section 8 of the New York Constitution, the entire text of the material sought to be incorporated by reference must first be filed with the department of state."139

\footnotetext{
135 N.Y. EXEC. L. § 102(1)(c) (McKinney 2011).

${ }^{136}$ Law of 1984 , ch. $941 \S 1$. While the legislative library - which is a small library on the same floor of the State Capitol as the Assembly and Senate - does have some record keeping responsibilities (see N.Y. STATE PRINT. \& PUB. Docs. L. § 11 (McKinney 2021)), it largely serves as a reading room for legislators, staff, lobbyists, and visitors to the Capitol building. It is an extremely unlikely setting for a repository library. There is legislation pending in 2021 which would upgrade the legislative library by establishing a separate "division of research and analysis" with the library. See Assemb. B. 304, 2021 Leg., 244th Sess. (N.Y. 2021); S.B. 622, 2021 Leg., 244th Sess. (N.Y. 2021).

${ }^{137}$ N.Y. EXEC. L. § 102(4)(c) (McKinney 2021); see 2011 N.Y. Sess. Laws 571 S. 4820 (McKinney).

138471 N.Y.S.2d 498 (Co. Ct. 1984).

${ }^{139}$ Id. at 501. See People v. Roth, 492 N.Y.S.2d 971 (Co. Ct. 1985), for a general history of the litigation involving the filing of incorporated rules by the Department of Environmental Conservation. See also the Department of Environmental Conservation's administrative law judge decision in Robert Berger, No. CO3-
} 
The effect of these decisions and the subsequent law would seem to be that incorporation by reference is permitted for state rules and regulations. However, given the need for the filing of incorporated material at the time of the promulgation of the rule, dynamic incorporation would in theory be forbidden. No government agency can possibly file and anticipate future changes in federal regulations or non-governmental codes or standards at the time of rule promulgation.

There are also a host of legal and policy questions raised by the conjunction of Article IV, Section 8 of the Constitution and Section 102 of the Executive Law. Is a regulation valid if it complies with Article IV, Section 8 but fails to comply with Section 102? What would happen if the incorporated materials could not be located at one of the court's law libraries or at the legislative library? ${ }^{140}$

Is there anyone seriously reviewing the proposed regulations to assure compliance with Section 102? What happens during a pandemic when there is no public access to the courts, the legislative library, or the Department of State? How can a member of the public possibly be aware of materials that have been incorporated by reference? For example, podiatry fee schedules might not be accessible in government offices for workers' compensation services during a pandemic. ${ }^{141}$ The fee schedule is available on the internet, ${ }^{142}$ but there may be a cost to access the fee schedule. ${ }^{143}$ Some of the materials referenced by rules of the Department of State are purchasable only from the International Code Council which publishes these codes. ${ }^{144}$ What is the proper way to handle materials that have

20070201-9, 2011 WL 6934250 (N.Y. Dep't Env’t Conservation Aug. 22, 2011). The administrative law judge stated, "There is nothing to suggest that Attco Metals 'lacks legal authority." Id. at *7. It has not been overturned and remains good law."

${ }^{140}$ What if the agency filing the incorporated reference fails to have the material filed in the Thirteenth Judicial District in Staten Island, Richmond County, which was first created in 2007? Would materials incorporated by reference before 2007 need to be refiled in Staten Island in order to comply with section 102 ?

${ }^{141}$ N.Y. WORKERS' COMP. LAW $\$ 343.2$ (McKinney 2020).

142 Official New York State Workers Compensation Podiatry Fee Schedule, N.Y. Workers' Compensation Bd., https://www.optum360coding.com/upload/docs/Official_New_York_State_Worker s_Compensation_Podiatry_Fee_Schedule_Updated_Pages_Effective_January_1_2 020.pdf (Jan. 1, 2020).

${ }^{143} \mathrm{Id}$.

${ }^{144}$ See, e.g., N.Y. COMP. CODES R. \& REGS. tit. 19, $\S \S 1219.2,1225.2,1240.4,1227.2$ (2020). 
been incorporated by reference but are subject to copyright protection? ${ }^{145}$ What happens to materials that were previously readily available on the internet but have since been removed? Similarly, what happens when web addresses are changed?

In 1984, the New York State Government specifically designated agencies that would review proposed rules and regulations by establishing the State Office of Business Permits and Regulatory Affairs to help review the content of rules. ${ }^{146}$ The Office of Business Permits and Regulatory Affairs was succeeded in 1995 by the Governor's Office of Regulatory Reform. ${ }^{147}$ Both agencies reviewed proposed rules and regulations to determine whether they were properly authorized. In 2011, the Governor's Office of Regulatory Reform was discontinued, ${ }^{148}$ and there is no longer a single government agency dedicated to ensuring that rules are properly written. ${ }^{149}$ With only limited review of proposed rules, it has become increasingly possible for rules with dynamic incorporation by reference to be promulgated.

Thus, there are numerous rules that involve dynamic incorporation by reference. For example, one of the rules of the Office of Alcoholism and Substance Abuse Services purports to incorporate the "most current revision and publi[cation]" of a number of reference works such as the Diagnostic and Statistical Manual of Mental Disorder, The International Classification of Diseases, and The Medicare Provider Reimbursement Manual. ${ }^{150}$ This can hardly be viewed as anything other than a dynamic incorporation by reference.

Numerous New York State agency rules reference the consumer price index, which changes on a monthly basis. They utilize the consumer price index to adjust payments tied to contracts, ${ }^{151}$ for

\footnotetext{
${ }^{145}$ See Bremer, supra note 24.

${ }^{146}$ Law of 1984, ch. 698; see also Harold I. Abramson, Regulating the Regulators in New York State, 58 N.Y. BAR J. 22 (1986).

${ }^{147}$ N.Y. COMP. CODES R. \& REGS. tit. 9, § 5.20 (1995).

${ }^{148}$ Law of 2011, ch. 60; N.Y. COMP. CODES R. \& REGS. tit. 9, § 8.14 (2011).

${ }^{149}$ A small unit inside the State Division of the Budget, the Regulatory Review Unit, was designated as the successor to the Governor's Office of Regulatory Reform under N.Y. COMP. CODES R. \& REgS. tit. 9, § 8.14.

${ }^{150}$ N.Y. COMP. CODES R. \& REGS. tit. 14, § 800.2(a), (e)-(f) (2002).

${ }^{151}$ N.Y. COMP. CODES R. \& REGS. tit. 8, § 156.5 (2020).
} 
tax purposes, ${ }^{152}$ for fee adjustments, ${ }^{153}$ and to determine beneficiary payment levels. ${ }^{154}$ While there is one case finding that incorporation by reference of the consumer price index is not an improper incorporation by reference, ${ }^{155}$ the notion expressed in that case that the index and its calculation were simply ministerial determinations, ${ }^{156}$ hardly seems justifiable. Numerous subjective decisions are involved when calculating the consumer price index. ${ }^{157}$

The rules of several state agencies grant the Financial Accounting Standards Board ("FASB") powers to determine conformity with generally accepted accounting principles. Members of the FASB include the Public Service Commission, ${ }^{158}$ the Department of Health, ${ }^{159}$ the Office of General Services, ${ }^{160}$ the State Education Department, ${ }^{161}$ and the Banking Department. ${ }^{162}$ Many of the references to compliance with standards of the FASB do not refer to particular standards or the dates of those standards, thus making them dynamic incorporations by reference. ${ }^{163}$

The statutes governing the State Insurance Department ${ }^{164}$ include a large number of references to the National Association of Insurance Commissioners, and the head of the agency may even

152 N.Y. COMP. CODES R. \& REGS. tit. 20, § 9-1.1 (2016).

153 N.Y. COMP. CODES R. \& REGS. tit. 3, § 400.11 (2019); N.Y. COMP. CODES R. \& REGS. tit. 21, § 10085.16 (2010).

154 N.Y. COMP. Codes R. \& REGS. tit. 11, §§ 42-2.11, 59.5 (2008); N.Y. COMP. CODES R. \& REGS. tit. 14, § 841.10 (2015).

${ }^{155}$ Eastern Air Lines, Inc. v. Dep’t of Revenue, 455 So.2d 311, 316 (Fla. 1984).

${ }^{156} I d$.

157 The index for one item in the consumer price index might seem objective, but the overall determination of the items in the index and weighing of those items is decidedly controversial. See Barclay Palmer, Why Is the Consumer Price Index Controversial?, INVESTOPEDIA, https://www.investopedia.com/articles/07/consumerpriceindex.asp (Dec. 11, 2020); see also Consumer Price Index, BRITANNICA, https://www.britannica.com/topic/consumer-price-index (last visited Feb. 15, 2021).

${ }^{158}$ N.Y. COMP. CODES R. \& REGS. tit. 16, § 899.10.

${ }^{159}$ N.Y. COMP. CODES R. \& REGS. tit. 10, § 442.21.

${ }^{160}$ N.Y. COMP. CODES R. \& REGS. tit. 9, § 335.7.

${ }^{161}$ N.Y. COMP. CODES R. \& REGS. tit. 8, § 29.10.

162 N.Y. COMP. CODES R. \& REGS. tit. $3, \S 410.1$.

${ }^{163}$ See, e.g., N.Y. COMP. CODES R. \& REGS. tit. 16, § 899.10; N.Y. COMP. CODES R. \& REGS. tit. 8, § 29.10 (2021); N.Y. COMP. CODES R. \& REGS. tit. 9, § 335.7.

164 The Insurance Department is now a part of the Department of Financial Services. See N.Y. FIN. SERV. L. § 101-a (McKinney 2011). 
designate the National Association of Insurance Commissioners or its subsidiaries "to perform ministerial functions, including the collection of fees, related to producer licensing under this article that the superintendent may deem appropriate." 165 The Insurance Department has, by rule, adopted by reference some of the standards and manuals of the National Association of Insurance Commissioners. There are also rules where the extent and details of such references are set out in the rules themselves. ${ }^{166}$ There are also regulations which mention the National Association of Insurance Commissioners while failing to comply with Section 102 of the Executive Law. ${ }^{167}$ Meanwhile, references to the National Association of Insurance Commissioners can raise significant issues due to the impermissible use of dynamic incorporation by reference. ${ }^{168}$

Similarly, there are rules delegating authority to the Public Company Accounting Oversight Board which could potentially be viewed as dynamic. ${ }^{169}$

Overall, there are many significant issues involving New York State rulemaking and the issue of incorporation by reference.

${ }^{165}$ N.Y. INS. L. § 2135 (McKinney 2004).

166 See N.Y. COMP. CODES R. \& REGS. tit. 11, § 83.4 (2021); NAT'L AsS'N OF INS. COMM'Rs, STATES' PRESCRIBED DiFFERENCES FROM NAIC StatUTORY ACCOUNTING PRINCIPLES (2020). On updating the National Association of Insurance Commissioners manual, see N.Y. COMP. CODES R. \& REGS. tit. 11, § 83.2(g)(4) (2021) ("It is the superintendent's intention to update this Part each year in order to adopt the newly published accounting manual, subject to such exceptions (as set forth in section 83.4 of this Part) as may be appropriate because of New York law or policy. If it becomes necessary for the superintendent to apprise the public and the insurance industry of new information regarding accounting practices prior to the next updating of this Part, the superintendent may issue circular letters to provide advice and instruction, or the superintendent may amend this Part as appropriate.").

${ }^{167}$ See N.Y. Comp. Codes R. \& Regs. tit. 11, § 53-3.7 (2021); N.Y. COMP. CODES R. \& REGS. tit. 11, § 89.5 (2021).

${ }^{168}$ See Schwarcz, supra note 7, at 239-40. See generally Bruce Edward Committee, The Delegation and Privatization of Financial Accounting Rulemaking Authority in the United States of America, 1 CRITICAL PERSPS. ON ACCT. 145 (1990).

${ }^{169}$ See N.Y.COMP. CODES R. \& REGS. tit. 11 § 89.8 (2021) (“A company shall require that if the CPA, subsequent to the date of the audited financial report filed pursuant to this Part, becomes aware of facts that might have affected the report, the CPA acts in accordance with professional obligations imposed by the AICPA and PCAOB."); see also N.Y. COMP. CODES R. \& REGS. tit. 10 § 98-3.2 (2021). 


\section{INCORPORATION BY REFERENCE AND LOCAL GOVERNMENT}

In theory, there should be nothing preventing local government from using incorporation by reference in their laws and codes. The constitutional ban, contained within an article of the constitution that is dedicated to the legislature, only applies to legislative acts. There is no provision akin to Article IV, $\S 8$ requiring that referenced materials are kept on file. Yet, at least early on, administrative agencies took the position that the constitutional ban in Article III, $\S 16$ should apply to local governments.

In 1964, the Attorney General determined that Article III, § 16 prevented the city of Yonkers from adopting the National Electric Code by ordinance. ${ }^{170}$ If it wanted to adopt the National Electric Code, the city of Yonkers had to include it "word for word in full." 171

The State Comptroller took the same position as the Attorney General. In regards to the National Electric Code, the Comptroller in 1961 wrote,

It is our opinion that a Legislature which is forbidden by the State Constitution to incorporate by reference the substantive provisions of other statutes (State Const Art III, § 16) certainly does not possess the power to incorporate into one of its enactments, by reference, the provisions of the National Electrical Code. How much more intolerable would be an attempt by a municipality to incorporate into a municipal ordinance or local law the provisions of said Code. ${ }^{172}$

In 1966, the Comptroller similarly stated, based on his 1961 ruling, that a village could not incorporate the American Insurance Association's Fire Prevention Code by reference. ${ }^{173}$ According to the Comptroller, Article III, $\S 16$ 's ban on legislative incorporation by reference applied "to local legislative bodies." 174

Nevertheless, when the City of Syracuse incorporated the National Electric Code by reference, its actions were found to be

\footnotetext{
${ }^{170}$ Opinions, 1964 NY Att'y Gen. Rep. \& Op. 72, 72 (1916).

${ }^{171} \mathrm{Id}$.

172 Opinions, 1961 NYS Comp. \& Op. 61, 175 (1961).

${ }^{173}$ Opinions, 1966 NYS Comp. \& Op. 66, 856 (1966).

${ }^{174}$ Id.
} 
constitutional. ${ }^{175}$ Without discussing the issue of incorporation by reference the court stated,

The Common Council of the City of Syracuse has not delegated its lawful authority to set the standards by which electrical work is to be done. On the contrary, it has merely adopted the National Electrical Code and has incorporated this Code into its ordinance as part of the Electric Code of the City of Syracuse. ${ }^{176}$

Despite what the Comptroller had opined, the court found the incorporation of a private code to be valid.

Similarly, the Fire Prevention Code was adopted through incorporation by reference by Nassau County and quickly found its way into litigation. In the 1982 case of Island Swimming Sales, Inc. v. Nassau County, ${ }^{177}$ the Appellate Division found that Nassau County's adoption of the Fire Prevention Code was constitutional. In People v. Shore Realty Corporation, ${ }^{178}$ the Nassau County District Court directly referenced the holding in Island Swimming Sales when it wrote,

"Where, as here, specifically designated standards are adopted and incorporated into an ordinance by a legislative body; and such standards are possessed by said body at the time of enactment and are on file with the legislative body for all to peruse, the ordinance is valid even if such standards are not directly inserted within the body of the ordinance." 179

While the lower court's decision was reversed on appeal on procedural grounds, the decision authorizing incorporation by reference was unaffected.

The City Court of Long Beach found that Article III, $\S 16$ did not apply to localities. The court wrote, "[I]t may be fairly argued that article III applies to the New York State Legislature, its composition, powers, and duties, and not to local government. The latter is controlled by article IX of the State Constitution, which does not

\footnotetext{
${ }^{175}$ City of Syracuse v. Penny, 300 N.Y.S.2d 679, 683 (Sup. Ct. 1969).

${ }^{176} \mathrm{Id}$.

177452 N.Y.S.2d 68 (App. Div. 1982).

178486 N.Y.S.2d 124 (Dist. Ct. 1984).

${ }^{179}$ Id. at 127 (quoting Island Sale, Inc., 452 N.Y.S. 2d at 68).
} 
contain restrictions against 'incorporation by reference' in local ordinances." 180

Similarly, the Nassau County District Court, relying on the Supreme Court decision in Island Swimming Sales, found in 1984 that Nassau County's incorporation by reference of the code of the National Fire Protection Association was constitutional. ${ }^{181}$

In USA Baseball v. City of New York, ${ }^{182}$ New York City passed an ordinance banning the use of metal bats in high school baseball. ${ }^{183}$ The New York City Council accomplished this goal by incorporating by reference the rules of Major League Baseball banning non-wooden bats. ${ }^{184}$ The plaintiffs brought a broad constitutional challenge to the ordinance in federal court. One of the challenges was that the incorporation by reference violated Article III, § 16 of the State Constitution. ${ }^{185}$

The court found that New York City's use of Major League Baseball's rules did not present any constitutional problems. ${ }^{186}$ Instead, "New York courts have distinguished the incorporation of professional standards and codes from the kinds of delegations of sovereign or legislative functions that are impermissible under federal and state constitutional law." 187 Therefore, "[t]he Bat Ordinance's reliance on MLB's official rules is just the sort of incorporation by reference of a private body's standards that raises no concern about a delegation of legislative responsibility or abdication of sovereign authority." 188

The biggest issue regarding localities' practice of incorporation by reference is whether localities are authorized to utilize dynamic incorporation by reference. In USA Baseball, the federal court suggested that dynamic incorporation would be permissible. The

\footnotetext{
${ }^{180}$ People v. Halpern, 361 N.Y.S.2d 578, 583 (City Ct. 1974). The court added that even if Article III, Section 16 did apply to local governments, the prohibition "pertains to incorporation of other laws and not to standards prepared by private associations." Id.

${ }^{181}$ Shore Realty Corp., 486 N.Y.S.2d at 427.

182509 F. Supp. 2d 285 (S.D.N.Y. 2007).

${ }^{183} I d$. at 288.

${ }^{184} I d$. at 299.

${ }^{185} \mathrm{Id}$.

${ }^{186} I d$. at $299-300$.

${ }^{187} I d$. at 299.

${ }^{188} I d$. at $299-300$.
} 
scope of the incorporated material was circumscribed, and the court found that

there is no indication that MLB has made any dramatic change in its official rules with respect to allowable bats, and the suggestion that such a change could affect the Bat Ordinance's constitutionality is therefore hypothetical, speculative, and not ripe for decision at this time. The legislative adoption of MLB rules to a limited set of circumstances is consistent with the cases that have approved the incorporation of privately developed standards. ${ }^{189}$

On the other hand, New York courts have taken the position that dynamic incorporation by reference is improper.

In People v. Mobile Oil Corporation, ${ }^{190}$ Nassau County had passed an ordinance incorporating by reference the rules of the National Fire Protection Association. ${ }^{191}$ The ordinance specified that the future amendments to the National Fire Protection Association's rules would become part of the ordinance. ${ }^{192}$ The court found this dynamic incorporation to be an improper grant of sovereignty to a private entity. ${ }^{193}$ The court stated, "The County has relinquished all control over the ordinance in question pertaining to flammable and combustible liquids to the National Fire Protection Association .... . Such a procedure is an improper delegation of legislative authority, and therefore unconstitutional." 194

The Appellate Division reached a similar conclusion in 2011 in the case of Brookhaven Baymen's Association, Inc. v. Town of Southampton. ${ }^{195}$ The town of Southampton, in an ordinance regulating the taking of shellfish, had incorporated by reference the rules and regulations of a non-governmental organization, the trustees of the Freeholders and Commonalty of the Town of Southampton. The court determined that it was proper for the town to incorporate the rules and

\footnotetext{
${ }^{189} \mathrm{Id}$. at 300.

190422 N.Y.S.2d 589 (Dist. Ct. 1979).

${ }^{191} \mathrm{Id}$. at 589.

192 Id. at 589-90.

${ }^{193} I d$. at 592.

${ }^{194} I d$.

195926 N.Y.S.2d 594 (App. Div. 2011).
} 
regulations of the non-governmental trustees. ${ }^{196}$ Nonetheless, the Town of Southampton failed to establish that this incorporation by reference was not an open-ended delegation. ${ }^{197}$ Instead, the local law "permits the Trustees, from time to time, at their prerogative, to amend their regulations, and [. . .] compliance with them would be required, without the Town Board ever having reviewed and voted on the amended regulations." 198 Accordingly, given the dynamic effect of the ordinance, a cause of action was properly stated to challenge the ordinance.

The case law in New York clearly authorized localities to utilize incorporation by reference in their local laws. ${ }^{199}$ While incorporation by reference is recognized at the local level, the few New York cases that have reviewed the issue have found that dynamic incorporation by reference is not allowed. ${ }^{200}$ Nonetheless, in one case a federal court applying New York law did find that dynamic incorporation could be authorized. ${ }^{201}$

\section{THE STATE OF INCORPORATION BY REFERENCE IN NEW YORK}

It is self-evident that the law governing incorporation by reference in New York is close to chaotic. Incorporation by reference in state legislation is technically banned by the Constitution. The Constitution literally limits the ban on incorporated material to "existing law"202 Yet, opinions have not limited the ban on incorporation to existing law in New York State. ${ }^{203}$ On the other hand, the Constitution allows exceptions to the incorporation for reference ban in bills drafted by "commissioners or any public agency appointed

\footnotetext{
${ }^{196} I d$. at 597 (citing Shore Realty Corp., 486 N.Y.S.2d at 124, as authority for the right of a locality to incorporate by reference the rules of a private organization).

${ }^{197} I d$.

${ }^{198} \mathrm{Id}$.

${ }^{199}$ See cases cited supra notes $175,177,180-81$.

${ }^{200}$ See cases cited supra notes 190, 197.

${ }^{201}$ USA Baseball v. City of New York, 509 F. Supp.2d 285, 299-300 (S.D.N.Y. 2007).

${ }^{202}$ N.Y. CONST. art. III, § 16 (2002).

${ }^{203}$ See Darweger v. Staats, 196 N.E. 61, 72 (N.Y. 1935); New YoRk STATE LEGiSLATURE, supra note 44, at 830; REVISED RECORD OF THE CONSTITUTIONAL Convention of the State of New York: April Sixth to SEPTEMBER TENTH, 1915830 (1916). See also People v. Parker, 539 N.E.2d 348, 352 (N.Y. 1976).
} 
or directed pursuant to law to prepare revisions"204 and for federal income tax laws. ${ }^{205}$ Moreover, the courts have viewed the ban on incorporation by reference in an extremely narrow manner. There is no case law regarding whether dynamic incorporation by reference is permitted. Currently, it is specifically authorized for federal tax materials. ${ }^{206}$ The need for a specific authorization to utilize dynamic incorporation might lead to the conclusion, under the principle of expressio unius est exclusio alterius, ${ }^{207}$ that dynamic incorporation would not be acceptable in case of statutes that lack a constitutional exception. ${ }^{208}$

As to rules of state agencies, incorporation by reference is clearly authorized so long as the referenced material is on file with the Secretary of State. That would seem to preclude any possibility of dynamic incorporation of reference. Yet, there are extant rules which clearly purport to encompass dynamic incorporation. Most importantly, there are real questions as to whether the public has adequate notice of the content of the material that is being referenced. The concerns are only heightened during public health emergencies, when the public has limited or no access to locations where the rules are on file.

Finally, local enactments can employ incorporation by reference. There is no requirement that the referenced matter has to be part of a public filing, and it is likely that dynamic incorporation by reference is not authorized.

\footnotetext{
${ }^{204}$ N.Y. CONST. art. III, $\S 21$ (2002).

205 N.Y. CONST. art. III, § 22 (2002).

${ }^{206} I d$.

207 The "specific mention of one person or thing implies the exclusion of other persons or things.” N.Y. STAT. $§ 240$ (McKinney 2021); see also Cordiano v. Metacon Gun Club, Inc., 575 F.3d 199, 221 (2d Cir. 2009).

208 The statutory constructive maxim of expressio unius est exclusio alterius means "that where a law expressly describes a particular act, thing or person to which it shall apply, an irrefutable inference must be drawn that what is omitted or not included was intended to be omitted or excluded" See N.Y. STAT. § 240 (McKinney 2021). Additionally, dynamic incorporation allows parties other than the legislature to change state law, and that might not be acceptable under the New York Constitution's exclusive grant of legislative authority to the New York State Assembly and Senate under Article III, § 1. See Schumer v. Caplin, 150 N.E. 139, 140 (N.Y. 1925) ("A constitutional statute, once passed, cannot be changed or varied according to the whim or caprice of any officer, board, or individual. It remains fixed until repealed or amended by the Legislature.").
} 


\section{HOW TO MAKE NEW YORK'S INCORPORATION BY REFERENCE REGIMEN COHERENT}

There is seemingly no reason why there are different rules for incorporation by reference for state legislation, state agencies, and local governments. While it may not be possible to treat the levels of government with equal precision, the goal should be to make the process as similar as possible for each level.

The first, and most significant, way to achieve equality of treatment is to repeal Article III, $\S 16$ of the State Constitution. There is no reason for the incorporation by reference provision in the State Constitution to continue to exist. The exception to the provision - as well as the restrictive construction given to the provision by the courts - have made it of limited utility.

Several decisions that have found violations of Article III, $\S 16$ could have been reached on alternate grounds. In some instances, the legislation would have been void for vagueness, ${ }^{209}$ and in others, it would have been viewed as a violation of Article III, § 1's guarantee that legislative power was vested in the State Assembly and Senate. ${ }^{210}$ Using these constitutional criteria, the results would not have changed.

Instead, we are left with an incorporation by reference provision that is the same as it was in 1915. In the words of Constitutional Convention delegate Richard Smith,

It stands here as a bugbear every time we draft a statute, to determine whether a reference to what we believe to be procedure or administrative detail will be held by the court to be procedure or administrative detail, or

\footnotetext{
209 The statute in the Becker case would certainly have been void for vagueness, and a reasonable case can be made that the statute at issue in Darweger was similarly unconstitutionally void. Legislation that would be void for vagueness would not only be invalid under the Due Process Clause of the $14^{\text {th }}$ Amendment, but would similarly be invalid under the State's due process clause, Article I, $\S 6$, which provides that "no person shall be deprived of life, liberty or property without due process of law." $C f$. New York State Rifle \& Pistol Ass'n, Inc. v. Cuomo, 804 F.3d 242, 265 (2d Cir. 2015).

${ }^{210}$ See Darweger v. Staats, 196 N.E. 61, 70 (N.Y. 1935); see also Levine v. O’Connell, 88 N.Y.S.2d 672 (App. Div. 1949).
} 
whether the court will say that it affects some substantive branch of the law. ${ }^{211}$

Delegate Smith proved to be correct by worrying about the provision of incorporation by reference. It is simply a potential land mine that accomplishes little and can only serve to thwart the intention of the legislative draftsmen. Incorporation by reference is a legitimate, traditional part of legislative drafting, and there is no need for the State Constitution to vilify and ban the practice.

Second, there needs to be transparency in the materials that have been incorporated by reference. The public has to know which materials have been incorporated and must have access to these materials. The current system provides no uniformity and no guarantee the public will have access to the materials that have been referenced. There is no reason why people should be charged a fee to view and review standards and codes that govern their behavior.

For legislation, whenever a bill purports to incorporate by reference the standards of a non-governmental organization, ${ }^{212}$ the fact of that incorporation should be noted in the introducer's memo in support of the legislation. ${ }^{213}$ That introducer's memo should also note where the public can access the referenced material. ${ }^{214}$

Similar to the sponsor's memo for the legislature, agency rules should note their incorporated material in the State Register. ${ }^{215}$ Furthermore, besides the constitutional requirement that the referenced

${ }^{211}$ REVised Record of the CONSTITUTIONAL CONVENTION OF THE STATE OF NEW YORK: APRIL SIXTH TO SEPTEMBER TENTH, 1915827 (1916).

212 The need to note the reference is far more significant for material being incorporated from non-governmental sources than from state laws, state rules, federal laws, and federal rules. This is because it is far harder for members of the public to access non-governmental sources than it is for them to access formally codified laws and rules.

${ }^{213}$ See N.Y. State Assemb. Res. 9, Rule III, § 1.f (2021).

214 Pending 2021 legislation would require the introducer's memo to include a statement of fiscal impact upon political subdivisions. See S. 3978, 2021-2022, Reg. Sess. (N.Y. 2021); S. 656, 2021-2022, Reg. Sess. (N.Y. 2021). Accordingly, this could be accomplished by statute or by rules of the individual houses of the legislature.

${ }^{215}$ This is hardly an imposition, as there are literally hundreds of examples in the State Register where the agency promulgating the rule has stated the specific material that it was incorporating. See, e.g., 42 N.Y. REG. 27 (Nov. 4, 2020); 42 N.Y. REG. 14 (Dec. 23, 2020); 41 N.Y. REG. 13 (Mar. 27, 2019); 41 N.Y. REG. 1 (Jan. 2, 2019). 
material be filed with the New York Secretary of State, ${ }^{216}$ the referenced material coming from a non-governmental organization must be filed on the website of the state agency promulgating the rule. If we want the public to have notice of the referenced material, the referenced material should be readily accessible.

The same procedure should apply to local governments. There needs to be full disclosure of the incorporation by reference, and the referenced material taken from a non-governmental organization should be published on the local government's website.

That leaves the ever-thorny problem of dynamic incorporation by reference. One simple solution, from the incorporation by reference framework, is to punt. Dynamic incorporation is not truly an incorporation by reference issue. It essentially focuses on the degree of authority a legislative body may delegate to another governmental body or a non-governmental organization. Is dynamic incorporation a surrender of legislative sovereignty? Should the New York State Constitution handle it as more of an Article III, $\S 1$ issue? Or an Article III, § 16 issue?

Yet, there needs to be a more thoughtful way to analyze dynamic incorporation. It is clear that local governments and state agencies do not have the authority to employ dynamic incorporation by reference, even if the actual agency rulemaking process has occasionally tended to break down.

But, given the minimal effect of the constitutional ban on state legislative incorporation by reference, should the state legislature have more ability to employ incorporation by reference than other units of government? Should only federal laws and federal rules be the subject of dynamic incorporation by reference? It has not presented issues for federal income tax legislation in New York. Does it make more sense to incorporate by reference materials that were the products of democratic governmental processes? ${ }^{217}$ Legislative incorporation by reference of federal or other state laws does present certain benefits. Some benefits from dynamic incorporation can include "avoiding unnecessary costs by free-riding on the lawmaking efforts of other polities; customizing the law to local conditions; and coordinating the

\footnotetext{
${ }^{216}$ N.Y. CONST. art. IV, $\S 8$.

217 See Dorf, supra note 27, at 119-32 (discussing the relationship between dynamic incorporation and various democratic processes).
} 
efforts of actors in different jurisdictions." 218 The question should be whether these purported benefits are worth the risk of sacrificing state sovereignty.

Finally, would it be possible to accomplish a de facto version of dynamic incorporation by reference by giving state agencies the power to veto assumed incorporations? ${ }^{219}$ Several states have passed laws incorporating federal drug schedules while giving their state agencies the power to veto aspects, or to revise the application, of the federal law. ${ }^{220}$ The state laws were challenged on grounds that the states ceded their sovereignty to the federal government. ${ }^{221}$ But the veto power given to the state agencies, plus the general presumption of constitutionality of legislation, were sufficient to let the courts find the laws constitutional. ${ }^{222}$ The decisions did not appear to delve into the issue of the possible vagueness of the state statute, but the fact is that these decisions have the potential to let state legislatures make superficial efforts at dynamic incorporation.

Putting aside the multitude of issues that are presented by dynamic incorporation by reference, it is possible to amend New York law so that incorporation by reference is treated in basically the same manner at all levels of government. This can be accomplished by repealing the existing Constitutional provision purporting to ban legislative incorporation by reference, mandating formal disclosure of instances of incorporation of reference, and making certain that public access to materials incorporated by reference is both free and easy. We can only begin to resolve the public policy issues brought on by incorporation by reference until we create a coherent and transparent process for viewing incorporation by reference.

\footnotetext{
${ }^{218} I d$. at 132.

${ }^{219} I d$. at 109.

${ }^{220}$ See generally State v. Thompson, 627 S.W.2d 298 (Mo. 1982); Boyd, supra note 1.

${ }^{221}$ See generally Thompson, 627 S.W.2d; Boyd, supra note 1.

222 See generally Thompson, 627 S.W.2d; Ex parte McCurley, 390 So. 2d 25 (Ark. 1980); State v. King, 257 N.W.2d 693 (Minn. 1977); State v. Lisk, 204 S.E.2d 868 (N.C. Ct. App. 1974); Commonwealth v. Hamilton, 411 S.W.3d 741 (Ky. 2013). See also Boyd, supra note 1, at 1267-68.
} 